Original Paper

http://indexmedicus.afro.who.int

\title{
Adsorption of phenol from aqueous solutions onto natural and thermally- modified kaolinitic materials
}

\author{
Julius NUMBONUI GHOGOMU ${ }^{1 *}$, Dieudonné TSEMO NOUFAME ${ }^{1}$, \\ Estella BULENG NJOYIM TAMUNGANG ${ }^{1}$, Dodo Lydie AJIFACK ${ }^{1}$, \\ Julius NSAMI NDI $^{2}$ and Joseph MBADCAM KETCHA ${ }^{2}$ \\ ${ }^{1}$ Laboratory of Noxious Chemistry and Environmental Engineering, Department of Chemistry, \\ Faculty of Science, University of Dschang, Cameroon. \\ ${ }^{2}$ Physical and Theoretical Chemistry Laboratory, Department of Inorganic Chemistry, \\ Faculty of Science, University of Yaoundé I, Cameroon. \\ *Corresponding author; E-mail: ghogsjuju@hotmail.com; Tel: (237) 77770003, \\ Fax: (237)33451381; P.O. Box 67 Dschang, Cameroon.
}

\begin{abstract}
Phenol removal from aqueous solutions by kaolinite (KAO) and metakaolinite (MET) have been carried out at $25^{\circ} \mathrm{C}$ in batch mode to evaluate the effects of parameters such as $\mathrm{pH}$, initial phenol concentration and adsorbent mass on the extent of adsorption. It was observed that phenol uptake increased with increases in adsorbent concentration at maximum $\mathrm{pH}$ of 2 and equilibrium time of 40 minutes for both KAO and MET. Results showed that pseudo second-order kinetic model best describes the chemisorption of phenol from aqueous solutions onto the two clay samples. The low correlation coefficient of the intraparticle diffusion model proves that pore diffusion plays little or no significant role in the adsorption of phenol onto KAO and MET. Also, from adsorption isotherm analysis, only the Temkin equation modeled best the adsorption process of phenol from aqueous solutions onto MET while the Freundlich and Temkin models best described the adsorption of phenol onto KAO. Maximum adsorption capacity for KAO and MET were 1.71 and $5.82 \mathrm{mg} / \mathrm{g}$ respectively through Langmuir model equation. It can be inferred from experimental results and modeled parameters that clay samples are not very effective for the removal of phenol from aqueous solution.
\end{abstract}

(C) 2014 International Formulae Group. All rights reserved.

Keywords: Environment, clays, organic pollutants, Kinetic models, Isotherm models.

\section{INTRODUCTION}

Pollution by phenols is an important environmental issue. Phenols are common pollutants in wastewater generated from oil, gasoline, coal, paper, petrochemicals, pharmaceuticals, pesticides and dye manufacturing industries (Ekpete et al., 2010). They are considered as one of the primary pollutants in wastewater because they are harmful to organisms even at low concentrations and many of them have been classified as hazardous pollutants because of their potential hazards to human health. Chronic toxic effects due to phenolic compounds reported in humans include vomiting, difficulty in swallowing, anorexia, liver and kidney damage, headache, fainting and other mental disturbance (Ekpete et al., 
2012). The low volatility of phenol and its affinity to water make oral consumption of contaminated water the greatest risk to humans (Mostafa et al., 1989; Prpich and Daugulis, 2005). This aromatic compound is water soluble and highly mobile and as such, waste waters generated from industrial activities contain high concentrations of phenolic compounds (Dursun and Kalayei, 2005) which eventually reach down to streams, rivers, lakes and soils. Their ubiquity represents a serious ecological issue that calls for global attention (Sofia, 2005). In the past several decades, extensive research has been conducted to develop innovative and promising adsorbent material for dealing with the treatment of contaminated industrial effluents. There is a growing interest in cost effective innovative materials and methods that will be useful in the treatment of industrial waste streams (Chen and Zhao, 2010; Theivarasu et al., 2011). Many agricultural by-products that are available at little or no cost have been reported to be capable of removing substantial amounts of phenol derivatives from aqueous solutions (Okieimen et al., 2007; Uddin et al., 2007). In compliance with stipulated norms, many depollution techniques such as flocculation, chemical precipitation, solvent extraction, membrane processes (ion exchange or electrodialysis, reverse osmosis etc) and adsorption are used for wastewater treatment especially in the removal of organic compounds (Achour and Youcef., 2003). The adsorption technique is most convivial and economically viable as the adsorbent is easily regenerated (Ketcha and Bougo, 2010).The adsorptive properties of clay for the removal of the pollutants are well documented (Ghogomu et al., 2013). Most currently used adsorbents for phenolic compound removal include organic materials such as marine algae (Najua et al., 2008) activated carbon prepared from green algae and elais guineensis (Ola, 2007); malachite green (Rajesh et al., 2010) or inorganic such as goethite (Grossl et al., 1994), layered double hydroxides (Goswamee et al., 1998), laterite (Maji et al., 2007), used tyres and sawdust (Hamadi et al., 2001), activated carbon (Han et al., 2000), smectite (Ketcha et al., 2009), zeolite (Tahir et al., 1998), hydrated Iron hydroxyde and clay minerals such as kaolinites (Lazaridis et al., 2001). After testing for the adsorption of some inorganic pollutants such as Lead (Ghogomu et al., 2013) and mercury (Anagho et al., 2013) by Kaolinite and methakaolinite we envisage in this study, the adsorption of an organic pollutant (phenol with aromatic properties) onto two adsorbent materials viz Natural and thermally-modified Kaolinite.

\section{MATERIALS AND METHODS}

Raw samples of Kaolinite (KAO) made up of clay materials were collected locally from the south region of Cameroon. Metakaolinite (MET) was obtained from kaolinite by thermal treatment (calcinations). Analysis of the chemical composition of KAO and MET was by x-ray fluorescence.

\section{Preparation of adsorbent}

In order to enrich the collected clay samples in kaolinite before use, samples were soaked inside distilled water for $24 \mathrm{~h}$, then washed in a 100 micron sieve immediately afterwards and were finally sun-dried. This procedure was repeated once more but using a sieve of 80 microns. The kaolinitic product obtained $\left(\mathrm{Al}_{2} \mathrm{Si}_{2} \mathrm{O}_{5}(\mathrm{OH})_{4}\right)$ was oven-dried at $110{ }^{\circ} \mathrm{C}$ for $24 \mathrm{~h}$. After drying, $500 \mathrm{~g}$ samples of the kaolinite were weighed and grounded in a mortar with pestle to fine powder and sieved to 80 micron size. Metakaolinite was obtained from kaolinite by dehydroxylation in a carbolite furnace maintained at $700{ }^{\circ} \mathrm{C}$ for $24 \mathrm{~h}$ according to equation 1 below.
$\mathrm{Al}_{2} \mathrm{O}_{3} \cdot 2 \mathrm{SiO}_{3} \cdot 2 \mathrm{H}_{2} \mathrm{O} \mapsto \mathrm{Al}_{2} \mathrm{O}_{3} \cdot 2 \mathrm{SiO}_{3}+2 \mathrm{H}_{2} \mathrm{O}$ ..... (1)
The carbonized material was taken out, grounded to fine powder, then sieved to 80 micron size and was finally stored in vacuum desiccators. 


\section{Preparation of solutions \\ Stock solution of phenol}

$\left(\mathrm{C}_{6} \mathrm{H}_{5} \mathrm{OH}, \quad 99.5 \%\right.$, Merck-Aldrich) was prepared by dissolving $1.0 \mathrm{~g}$ of the salt in 1 Liter of distilled water to give a concentration of $1000 \mathrm{ppm}$. Serial dilutions for working solutions were made by diluting the stock solution in accurate proportions.

\section{pH adjustment solutions}

$\mathrm{pH}$ adjustment solutions were prepared using hydrochloric acid $(0.1 \mathrm{M}, 60 \%$, Riedel-deHaen) and sodium hydroxide $(0.1 \mathrm{M}$ of $98 \%$, Fluka) solutions respectively.

\section{Batch adsorption experiments}

Equilibrium and kinetic adsorption experiments were carried out in a temperature controlled batch adsorption reactor maintained at $25{ }^{\circ} \mathrm{C}$. All the experiments (except the study of the effect of $\mathrm{pH}$ ) were carried out at a $\mathrm{pH}$ of 7.5. For each experiment (except otherwise stated), $0.2 \mathrm{~g}$ of adsorbent were measured and put into a $250-\mathrm{mL}$ conical flask containing 25 $\mathrm{mL}$ of the phenol solution at the desired concentration that ranged between 20 and $160 \mathrm{ppm}$ in this study. After stirring the solution for a predetermined time interval (5-60 minutes) with a magnetic agitator, samples were then filtered, thus separating the solid/adsorbent from the liquid/solution phase. The filtered solution was analyzed spectrometrically to determine the concentration of the residual phenol using a UV-Visible spectrophotometer (CORNING6259) at $\lambda_{\max }=270 \mathrm{~nm}$. Adsorption data obtained from equilibrium studies (contact time and initiation concentration effects) were employed in the kinetic studies and the applicability of different adsorption isotherms to phenol. The percentage removal efficiency of the adsorbents $(\% \mathrm{R})$, which is the ratio between sorption capacity at time $t$ and the sorption capacity at equilibrium are calculated as follows:

$\%(\mathrm{R})$ adsorption $=100\left(\mathrm{C}_{\mathrm{o}}-\mathrm{C}_{\mathrm{t}}\right) / \mathrm{C}_{\mathrm{o}}$
$\mathrm{Q}_{\mathrm{t}}(\mathrm{mg} / \mathrm{g})=\left(\mathrm{C}_{\mathrm{o}}-\mathrm{C}_{\mathrm{t}}\right) \mathrm{V} / \mathrm{m}$

(2) $\mathrm{Q}_{\mathrm{e}}(\mathrm{mg} / \mathrm{g})=\left(\mathrm{C}_{\mathrm{o}}-\mathrm{C}_{\mathrm{e}}\right) \mathrm{V} / \mathrm{m}$

Where $C_{o}(\mathrm{mg} / \mathrm{L})$ and $C_{t}(\mathrm{mg} / \mathrm{L})$ are the liquid-phase concentrations of solute (adsorbate) at the origin and at given time $t$, respectively. $\quad \mathrm{C}_{\mathrm{e}}(\mathrm{mg} / \mathrm{L})$ is the equilibrium concentration of phenol, $\mathrm{V}(\mathrm{L})$ is the volume of the solution while $\mathrm{m}(\mathrm{g})$ is the mass $(\mathrm{m})$ of the adsorbent.

\section{Kinetic models}

Adsorption kinetics describes the relationship between the rate of solute uptake and adsorption time. In order to verify the adsorption kinetic models, the pseudo-firstorder, the pseudo-second-order, the Elovich and intraparticle diffusion models were applied to the experimental raw data.

\section{Pseudo first-order model}

This model is based on the assumption that the adsorption rate is proportional to the number of available sites (Augustine et al., 2007) and is calculated through the following equation:

$\mathrm{dQ}_{\mathrm{t}} / \mathrm{dt}=\mathrm{K}_{\mathrm{f}}\left(\mathrm{Q}_{\mathrm{e}}-\mathrm{Q}_{\mathrm{t}}\right)$

Where $Q_{t}$ and $Q_{e}(\mathrm{mg} / \mathrm{g})$ are the amounts of adsorbate retained per unit mass of adsorbent at given time and at equilibrium respectively. $\mathrm{K}_{\mathrm{f}}\left(\mathrm{min}^{-1}\right)$ is the rate constant of the adsorption process. By integrating between $t=0$ and $t=t$ (corresponding to $\mathrm{Q}_{t}=0$ and $\mathrm{Q}_{t}=\mathrm{Q}_{t}$ ), we obtain the following: $\ln \left(\mathrm{Q}_{\mathrm{e}}-\mathrm{Q}_{t}\right)=\ln \mathrm{Q}_{\mathrm{e}}-\mathrm{K}_{\mathrm{f}} t$ (4) Linear plots of $\ln \left(\mathrm{Q}_{\mathrm{e}^{-}}\right.$ $\mathrm{Q}_{t}$ ) versus $t$ were carried out in order to evaluate this kinetic model and to determine $\mathrm{Q}_{\mathrm{e}}$ and the rate constant from the intercept and slope respectively.

\section{Pseudo second-order model}

It is based on the assumption that adsorption rate is proportional to the square of the number of unoccupied sites (Ho and Mckay, 1998):

$\mathrm{dQ} / \mathrm{d} t=\mathrm{Ks}\left(\mathrm{Q}_{\mathrm{e}}-\mathrm{Q}_{t}\right)^{2}$

where $\mathrm{Ks}\left(\mathrm{mg} \cdot \mathrm{g}^{-1} \cdot \mathrm{min}^{-1}\right)$ is the rate constant. By integrating between $t=0$ and $t=t$ (corresponding to $\mathrm{Q}_{t}=0$ and $\mathrm{Q}_{t}=\mathrm{Q}_{t}$ ), we obtain the following: 
$\mathrm{t} / \mathrm{Q}_{t}=1 / \mathrm{KsQ}_{\mathrm{e}}{ }^{2}+t / \mathrm{Q}_{\mathrm{e}}$

The parameters $\mathrm{Ks}$ and $\mathrm{Q}_{\mathrm{e}}$ can be calculated from the intercepts and the slope of the graph of $t / \mathrm{Q}_{t}$ versus $t$.

\section{Elovich model}

Elovich equation is a rate equation based on the adsorption capacity $\mathrm{Q}_{t}(\mathrm{mg} / \mathrm{g})$, an equation that can be expressed as (Ketcha and Bougo, 2010):

$\mathrm{dQ}_{t} / \mathrm{dt}=\alpha \mathrm{e}^{-\beta \mathrm{Q}_{t}}$

where $\alpha=$ initial adsorption rate $\left(\mathrm{mg} \cdot \mathrm{g}^{-1} \cdot \mathrm{min}^{-1}\right)$ and $\beta$ is related to the extent of surface coverage and activation energy for chemisorption $(\mathrm{g} / \mathrm{mg})$.

By integrating between $t=0$ and $t=t$ (corresponding to $\mathrm{Q}_{t}=0$ and $\mathrm{Q}_{t}=\mathrm{Q}_{t}$ ), we obtain the following after some simplifications:

$\mathrm{Q}_{t}=\ln (\alpha \beta) / \beta+\ln t / \beta$

The value of the constants can be obtained from the slope and intercepts of a plot of $\mathrm{Q}_{t}$ versus $\log t$.

\section{Intra-particle diffusion model}

The intra-particle diffusion model equation can be written as follows (Ghogomu et al., 2013):

$\mathrm{Q}_{\mathrm{t}}=\mathrm{K}_{\mathrm{id}} t^{1 / 2}+\mathrm{C}$,

where $\mathrm{K}_{\mathrm{id}}$ is the intra-particle rate constant (mg. $\mathrm{g}^{-1} \cdot \mathrm{min}^{-1 / 2}$ ) and $\mathrm{C}$ is the intercept. By plotting $\mathrm{Q}_{t}\left(\mathrm{mg} \cdot \mathrm{g}^{-1}\right)$ versus $t^{1 / 2}$ one should obtain a linear graph if the intra-particle diffusion is involved in the adsorption process. If the straight line passes through the origin, the intra-particle diffusion is the rate limiting step.

\section{Adsorption models}

There are a number of sorption models developed to describe the adsorption mechanism and to fit the experimental adsorption data. Three models were used in this study in investigating the mechanism of phenol adsorption on our clay samples: the Langmuir, Freundlich and Temkin isotherms equations respectively.

\section{The Langmuir isotherm}

The mathematical expression of the
Langmuir isotherm can be written as (Ghogomu et al., 2013):

$\mathrm{Q} / \mathrm{Q}_{\mathrm{m}}=\mathrm{KC}_{\mathrm{e}} /\left(1+\mathrm{KC}_{\mathrm{e}}\right)$

In this equation, $\mathrm{C}_{\mathrm{e}}$ is the bulk equilibrium concentration of adsorbate in solution, $\mathrm{K}$ is an affinity constant, $\mathrm{Q}$ is the amount of the adsorbate at equilibrium concentration $\mathrm{C}_{\mathrm{e}}$ and $\mathrm{Q}_{\mathrm{m}}$ is the amount necessary for monolayer surface coverage by adsorbate. In this adsorption isotherm, an assumption is made that the energy of adsorption is constant at all concentrations up to the full coverage of the surface. The Langmuir equation can be rewritten in linear form as:

$\mathrm{C}_{\mathrm{e}} / \mathrm{Q}=1 / \mathrm{K} . \mathrm{Q}_{\mathrm{m}}+\mathrm{C}_{\mathrm{e}} / \mathrm{Q}_{\mathrm{m}}$

Equation (11) implies that a graph of $\mathrm{C}_{\mathrm{e}} / \mathrm{Q}$ versus $\mathrm{C}_{\mathrm{e}}$ should give a straight line.

\section{Freundlich isotherm}

Another type of equation which has been used in this work to fit the adsorption data is the Freundlich equation, which can be written as (Ketcha and Bougo, 2010):

$\mathrm{Q}=\mathrm{K}_{\mathrm{d}} \mathrm{Ce}^{1 / \mathrm{n}}$

In this equation, $Q$ is the amount adsorbed at the surface; $\mathrm{Ce}$ is the equilibrium concentration of adsorbate in solution, $K_{d}$ is the distribution coefficient and $\mathrm{n}$ is a correction factor related to the heterogeneity of the surface. Taking the logarithm of either sides of this equation, it can be rewritten as:

$\ln \mathrm{Q}=1 / \ln _{\ln } \mathrm{C}_{\mathrm{e}}+\ln \mathrm{Kd}$

From which we see that a plot of $\ln \mathrm{Q}$ versus $\ln C_{e}$ should give rise to a straight line with a slope of $1 / \mathrm{n}$ and intercept equal to $\ln K_{d}$ if the adsorption follows a Freundlich isotherm. Another type of equation which has been applied to our adsorption data is the:

\section{Temkin isotherm}

It is expressed in linear form by the following relationship between the amount adsorbed and concentration in solution (Ghogomu et al., 2013):

$\mathrm{Q}_{\mathrm{e}}=\mathrm{B}\left(\ln \mathrm{K}_{\mathrm{T}}+\ln \mathrm{C}_{\mathrm{e}}\right)$

where $\mathrm{B}=\mathrm{RT} / \mathrm{b}$ is related to the heat of adsorption, $\mathrm{T}$ is the absolute temperature, $\mathrm{R}$ is the universal gas constant. $B$ indicates the 
adsorption potential of the adsorbent and $\mathrm{K}_{\mathrm{T}}$ is the equilibrium binding constant. Similar to the Freundlich equation, the Temkin model takes into account the heterogeneity of the surface.

\section{RESULTS AND DISCUSSION \\ Characterization of adsorbent \\ Chemical composition of materials}

Metakaolinite (MET) was obtained from kaolinite by thermal activation (calcination). Analysis of the chemical composition of KAO and MET by X-ray fluorescence showed the following results in percentages for $\mathrm{KAO}$ : weight loss (5.05); $\mathrm{SiO}_{2}(49.52) ; \mathrm{Al}_{2} \mathrm{O}_{3}(32.04)$; $\mathrm{Na}_{2} \mathrm{O}$ (0.00); $\mathrm{TiO}_{2}(0.9864) ; \mathrm{Fe}_{2} \mathrm{O}_{3}(0.7526)$; $\mathrm{K}_{2} \mathrm{O}(0.689) ; \quad \mathrm{MgO}(0.125) ; \quad \mathrm{CaO}(0.0406)$; $\mathrm{SO}_{3}(0.037) ; \quad \mathrm{P}_{2} \mathrm{O}_{5}(0.034) ; \quad \mathrm{NiO}(0.0126)$; $\mathrm{Cr}_{2} \mathrm{O}_{3}(0.011) ; \quad \mathrm{CuO}(0.0078) ; \quad \mathrm{ZnO}(0.0057)$; $\mathrm{Ga}_{2} \mathrm{O}_{3}(0.005)$; $\mathrm{Rb}_{2} \mathrm{O}(0.0047)$ for a total of $100.0014 \%$.

And for MET: weight loss (5.05); $\mathrm{SiO}_{2}$ (46.99); $\quad \mathrm{Al}_{2} \mathrm{O}_{3}(34.66) ; \quad \mathrm{Na}_{2} \mathrm{O}(10.55)$; $\mathrm{TiO}_{2}(0.941) ; \quad \mathrm{Fe}_{2} \mathrm{O}_{3}(0.7889) ; \quad \mathrm{K}_{2} \mathrm{O}(0.685)$; $\mathrm{MgO}(0.156) ; \quad \mathrm{CaO}(0.0606) ; \quad \mathrm{SO}_{3}(0.04)$; $\mathrm{P}_{2} \mathrm{O}_{5}(0.03) ; \quad \mathrm{NiO}(0.0121) ; \quad \mathrm{Cr}_{2} \mathrm{O}_{3}(0.01)$; $\mathrm{CuO}(0.0077) ; \quad \mathrm{ZnO}(0.006) ; \quad \mathrm{Ga}_{2} \mathrm{O}_{3}(0.004)$; $\mathrm{Rb}_{2} \mathrm{O}(0.0045)$ for a total of $99,9958 \%$.

\section{FT-IR spectroscopy}

FT-IR spectroscopic measurements were carried out to characterize the Kaolinite (KAO) and metakaolinite (MET) samples and results have been illustrated in Figures 1 and 2 below.

The analysis of the first spectrum (Figure 1) show absorption bands at $3693 \mathrm{~cm}^{-1} ; 3656 \mathrm{~cm}^{-1}$; and $3620 \mathrm{~cm}^{-1}$ which corresponds to stretching vibrations of the hydroxyl $(\mathrm{OH})$ of $\mathrm{KAO}$, and average band at $1110 \mathrm{~cm}^{-1}$ by the $\mathrm{Si}-\mathrm{O}$ functional group and at 1000, 1025, $402 \mathrm{~cm}^{-1}$ for symmetric and asymmetric vibration of the $\mathrm{Si}-\mathrm{O}-\mathrm{Si}$ group. We also perceived a small band at $908 \mathrm{~cm}^{-1}$ for the deformation of the $\mathrm{Al}-\mathrm{OH}$ bond of the KAO. Also present is another band between $790-748 \mathrm{~cm}^{-1}$ which are translational vibration bands for $\mathrm{Si}-\mathrm{O}-\mathrm{Al}$ and finally a $\mathrm{Si}-\mathrm{O}$ $\mathrm{Si}$ characteristic band of KAO at $666 \mathrm{~cm}^{-1}$ is visible (Ghogomu et al., 2013). The result obtained here imply the existence of repulsive electrostatic interactions between the $\mathrm{OH}$ functional groups of $\mathrm{KAO}$ and that of phenol with the effect of reducing the adsorption capacity at the surface of the adsorbents. We also notice the hydrophobic character of the adsorbents due to the presence of siloxane groups (Si-O-Si) (Djebbar et al., 2012) which is in conformity with our results on the adsorption capacity of the sorbent materials vis-à-vis others from the literature cited below in the text (Table $1)$.

We observe on the second spectrum (Figure 2) that all the vibrational bands due to the hydroxyl group $(\mathrm{OH})$ are absent and only characteristic absorption bands for the $\mathrm{Si}-\mathrm{O}$ at $1042 \mathrm{~cm}^{-1}$, for $\mathrm{Si}-\mathrm{O}-\mathrm{Al}$ at $787 \mathrm{~cm}^{-1}$ and 542 $\mathrm{cm}^{-1}$ (Ghogomu et al., 2013) respectively are present.

\section{Pore size distribution by the Barret-Joyner- Halenda method (BJH)}

The BJH method establishes the link between thermodynamic, sorption isotherm, geometrical data, intrinsic properties of the solid and the pore size distribution. Classically, this method uses nitrogen at $77 \mathrm{~K}$ as adsorbate gas. The results of this distribution, adsorption and desorption isotherms (BET) obtained on metakaolinite only are presented on Table 1 and Figure 3 below.

This isotherm (Figure 3) is reversible and convex with relative pressure axis corresponding to type-3 hysteresis according to the nomenclature of International Union of Pure and Applied Chemistry (IUPAC). This type of hysteresis is often encountered with non-porous or macroporous materials characterized by weak affinity between adsorbent and adsorbate and within molecules as well.

\section{Effect of contact time}

The influence of contact time on the 
adsorption of phenol from aqueous solution onto the two clay samples has been presented on Figure 4 below. These results were obtained at $\mathrm{pH}=8.5$ with mixtures of $25 \mathrm{~mL}$ of phenol solution (at $100 \mathrm{mg} / \mathrm{L}$ ) with $0.10 \mathrm{~g}$ of the different adsorbents. Sorption equilibrium time was observed after 40 minutes for both KAO and MET for an equilibrium time range of 5-60 minutes. From this figure we observe that for a given time, phenol removal by MET is more effective than by KAO. It is also inferred here that adsorption takes place in two steps. The first step, between 0-10 minutes, is attributable to the presence of free adsorption sites at the surface of the adsorbent. The progressive occupation of these sites noticed as phenol molecules diffuses through the adsorbent pores comes to a halt followed by a saturation controlled by sorption equilibrium time, marking the second step. After the attainment of equilibrium, the quantity of solute removed from solution doesn't change significantly indicating that 40 minutes is sufficient time for equilibrium to be reached. From literature, Kannam (1998) working with tea powder and saw dust to remove phenol from its aqueous solutions obtained 180 minutes as contact time. Also, Singh et al. (1994) reported 120 minutes as equilibrium time for the removal of phenol from aqueous solutions by using impregnated ash. Qadeer and Rehan (2002) on their part, working with commercial activated carbon in the removal of phenol found that 5 minutes were required for the attainment of equilibrium. Comparing our results with similar works in the literature (Table 2, Figures 4 and 5), we notice that our clay samples are more efficient in the removal of phenol from aqueous solutions.

\section{Effect of adsorbent dosage}

The removal of phenol from aqueous solutions by the two clay samples was studied by varying the masses of the adsorbent from 0.1 to $0.7 \mathrm{~g}$ while maintaining the other parameters constant. The percentage removal of phenol as a function of adsorbent mass has been illustrated in Figure 5. This figure shows that the percentage adsorption of phenol increases with adsorbent dose up till $0.1 \mathrm{~g}(\mathrm{R}=45 \%$ for MET and $90 \%$ for KAO respectively) and stabilizes more or less thereafter where no significant increase is noticed. At this portion of the curves, adsorption is marginalized and becomes pretty constant (Ekpete et al., 2010). Adsorbent dosage has a direct effect on the adsorbate removal because of increases in adsorbent surface and the adsorption sites.

\section{Effect of initial concentration}

Figure 6 shows that the quantity of phenol taken up at equilibrium increases with initial concentration of phenol in the aqueous solutions used. Similar results were obtained by Ghogomu et al. (2013). This result is attributed to the fact that KAO and MET adsorb very little at low adsorbate concentrations. The increase in the quantity adsorbed with initial concentration of phenol increases the collisions between phenol molecules and adsorption sites. It can be noticed from this result that the quantity adsorbed remains constant (for concentrations greater than $200 \mathrm{mg} / \mathrm{L}$ ) as the adsorption sites become saturated while the exchange sites are filled. The conclusion here is that surface saturation at equilibrium depends on the initial concentration of the adsorbate solution.

\section{Effect of pH}

The effect of $\mathrm{pH}$ on phenol uptake from aqueous solutions has been studied within a $\mathrm{pH}$ range of 2-12. $\mathrm{pH}$ adjustments were done by addition of either $0.1 \mathrm{M} \mathrm{HCl}$ or $0.1 \mathrm{M} \mathrm{NaOH}$ to $100 \mathrm{mg} / \mathrm{L}$ solution of phenol. For KAO, the quantity of phenol adsorbed diminishes slightly with $\mathrm{pH}$ before reaching a plateau and we conclude that the adsorbed quantity may be $\mathrm{pH}$ independent. As concerns MET, this quantity is almost constant at the beginning and suddenly decreases with $\mathrm{pH}$. This sudden decrease in $\mathrm{pH}$ corresponds to the formation of phenolate ions. 
Phenol as a weak acid will undergo less adsorption at higher $\mathrm{pH}$ values because of the repulsive forces prevailing at higher $\mathrm{pH}$ values. Adsorption takes place only when the strong chemical bond between water and the adsorbate is broken. In addition, the adsorption force decreases as the repulsion between the adsorbent surface and the dissociated adsorbate increases. Also, we observe that the hydrophobic character of the materials is reinforced at low $\mathrm{pH}$ values thus rendering their surface less active.

\section{Adsorption kinetics}

Generally, kinetic studies of adsorption processes provide pieces of information on the adsorption mechanism, mode and speed of mass transfer from the liquid phase to the solid phase. Many kinetic models abound in the literature. (Ho and McKay, 1999). They are governed by parameters such as concentration, mass, $\mathrm{pH}$, working conditions, etc. In this work, kinetics of phenol adsorption have been studied according to four principal models: Pseudo-first-order, Pseudo-secondorder, Elovich kinetic model and Intra-particle diffusion model. Characteristic parameters have been obtained from linear plots of each model. Figure 8 shows the graph for the linear plot of quantity adsorbed versus time for the pseudo second-order model (obtained for the different clay samples) while Table 3 displays the different values of the parameters for the four different models. From this table, we infer that the adsorption of phenol onto the clay samples follow pseudo second-order kinetic model $\left(\mathrm{R}^{2}=\right.$ 0.994 for KAO and $\mathrm{R}^{2}=0.998$ for MET) and as a consequence classified as a chemisorption process. The different behaviors of the four kinetic samples to the adsorbents are attributed to structural differences between them (Rajesh et al., 2010). Results from intraparticule diffusion model show that the adsorption process is governed by external diffusion (Xiu-yan, 2010).

\section{Adsorption isotherms}

Equilibrium studies of the adsorption of phenol from aqueous solutions by KAO and MET have been carried out according to three isotherm models: Langmuir, Freundlich and Temkin adsorption isotherms. The summary of the constants governing these isotherm models have been presented on Table 4. From this table we observe a low maximum adsorption capacity for KAO and MET as 1.71 and $5.82 \mathrm{mg} / \mathrm{g}$ respectively from Langmuir isotherm model $\left(r^{2}=0.8937\right.$ for KAO and $\left.r^{2}=0.0294\right)$. Also, we observed from these results that while Freundlich $\left(r^{2}=0.9478\right)$ and Temkin $\left(r^{2}=0.9632\right)$ isotherm models best describe the adsorption phenomenon of phenol onto KAO, the Temkin $\left(r^{2}=0.9423\right)$ model only suits phenol adsorption for MET. This is supported by the values $0<1 / \mathrm{n}<1$ and a positive value for the adsorption energy, $\mathrm{B}_{\mathrm{T}}$, for KAO and MET, indicative of the endothermic nature of the adsorption process (Augustine et al., 2007). The compliance of the Temkin model is a testimony of adsorption of phenol from aqueous solution onto the clay samples and consequently explains the weak interaction at the adsorbent surface. We also notice here that $\mathrm{B}_{\mathrm{T}}$ for $\mathrm{KAO}$ is less than $8 \mathrm{~kJ} / \mathrm{mol}$ which means that interactions between adsorbent and adsorbate are weak and that the adsorption mechanism put into place is characterized by ion exchange. $\mathrm{B}_{\mathrm{T}}$ is greater than $8 \mathrm{~kJ} / \mathrm{mol}$ for MET so the interaction between the adsorbate and adsorbent is strong and the mechanism put into play is characterized by external diffusion of the adsorbate from the surface films to the adsorbent. On the basis of experimental results and the isotherm model parameters (Langmuir, Freundlich and Tempkin), it can be inferred that the multilayer sorption of phenol from aqueous solution onto heterogeneous surface of clay is feasible. 


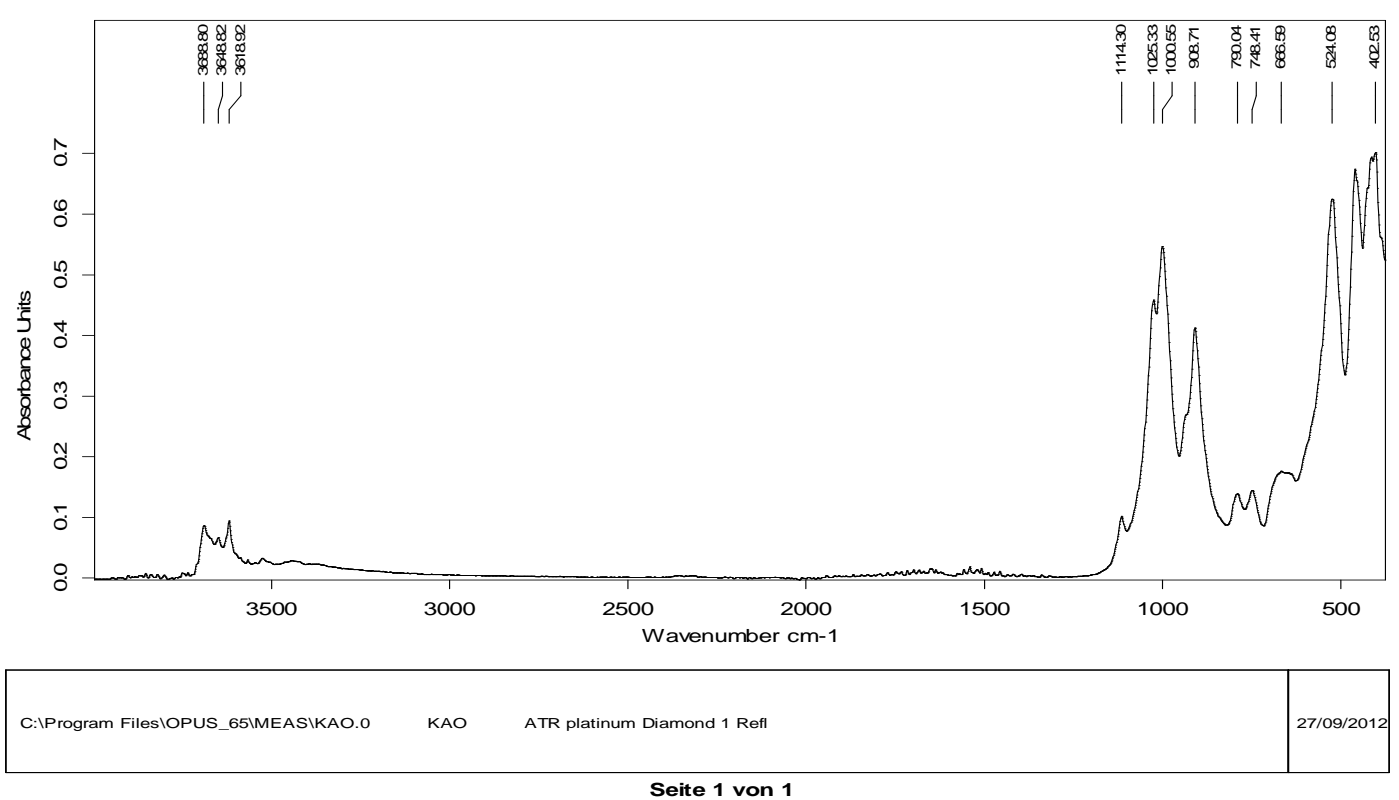

Figure 1: FT-IR spectrum of Kaolinite on platinium in $\mathrm{KBr}$ matrix.

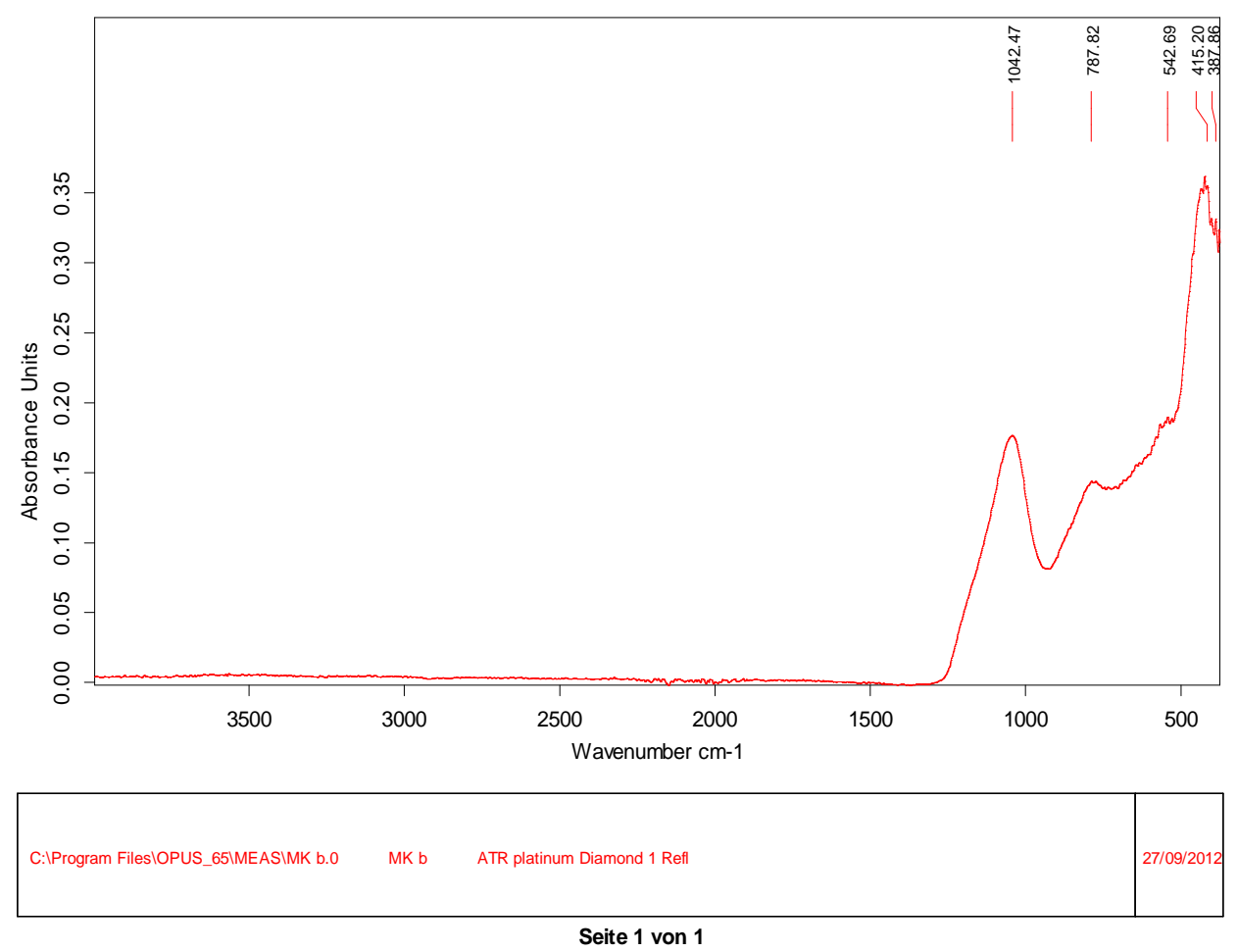

Figure 2: FT-IR spectrum of metakaolinite on platinium in $\mathrm{KBr}$ matrix. 


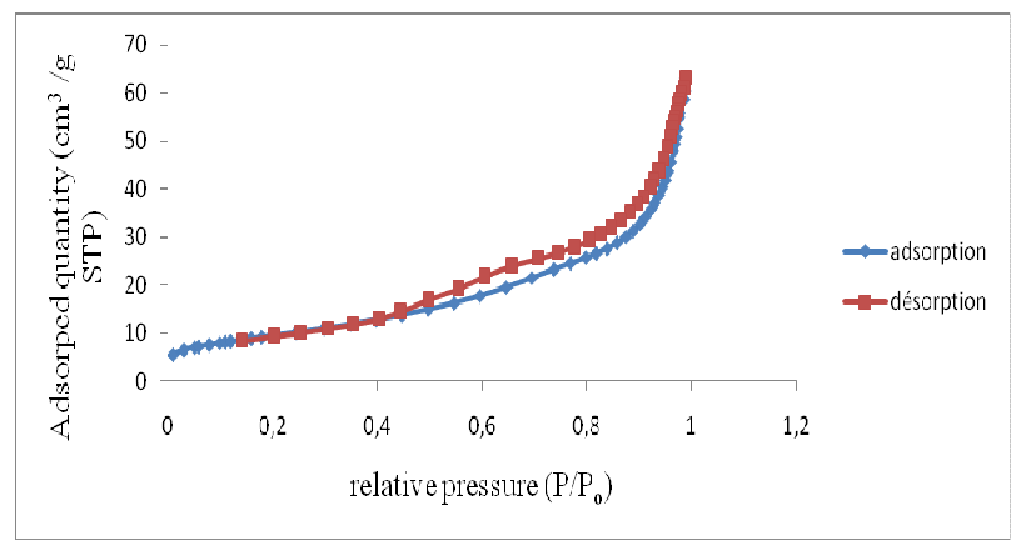

Figure 3: BET adsorption and desorption isotherm with nitrogen on metakaolinite at $77 \mathrm{~K}$.

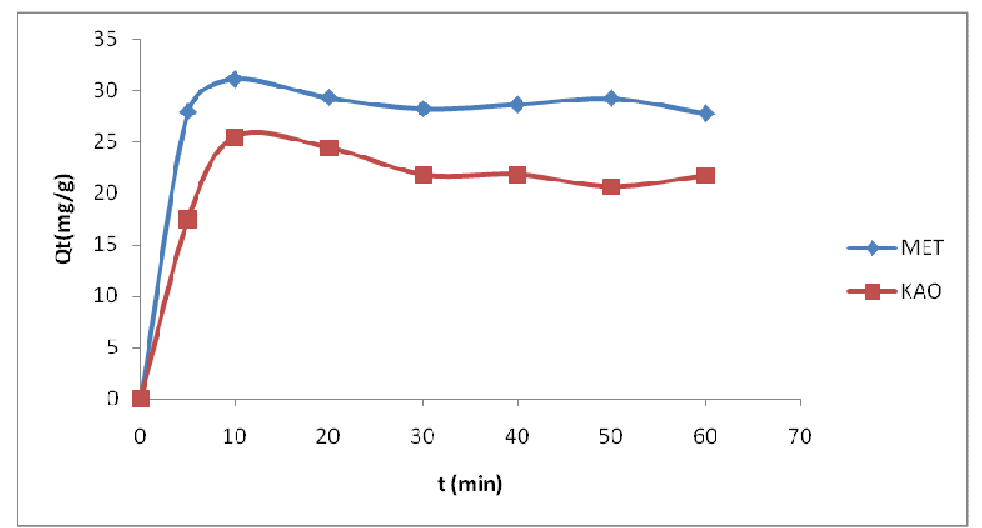

Figure 4: Influence of contact time on the sorption of phenol from aqueous solutions. $\mathrm{V}_{\mathrm{o}}=25 \mathrm{~mL} ; \mathrm{C}_{\mathrm{o}}=100 \mathrm{mg} / \mathrm{L}$ phenol solution; $\mathrm{m}_{\mathrm{o}}=0.1 \mathrm{~g}$ for KAO and MET; $\mathrm{pH}=8.5 ; \mathrm{T}=298 \mathrm{~K}$ ).

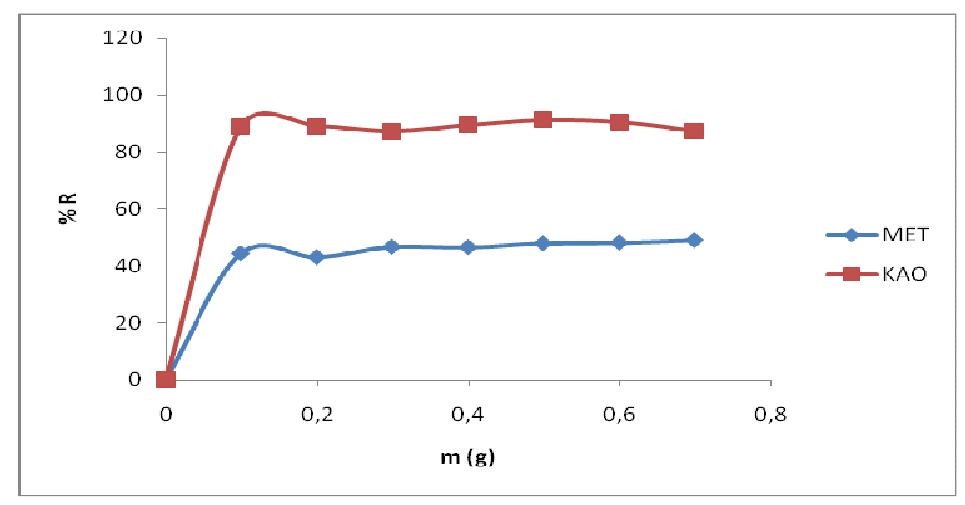

Figure 5: Influence of adsorbent dose on the sorption of phenol from aqueous solutions. $\left(\mathrm{V}_{\mathrm{o}}=25 \mathrm{~mL} ; \mathrm{C}_{\mathrm{o}}=100 \mathrm{mg} / \mathrm{L}\right.$ phenol solution; $\mathrm{pH}=8.5$; teq $\left.=40 \mathrm{~min} ; \mathrm{T}=298 \mathrm{~K}\right)$. 


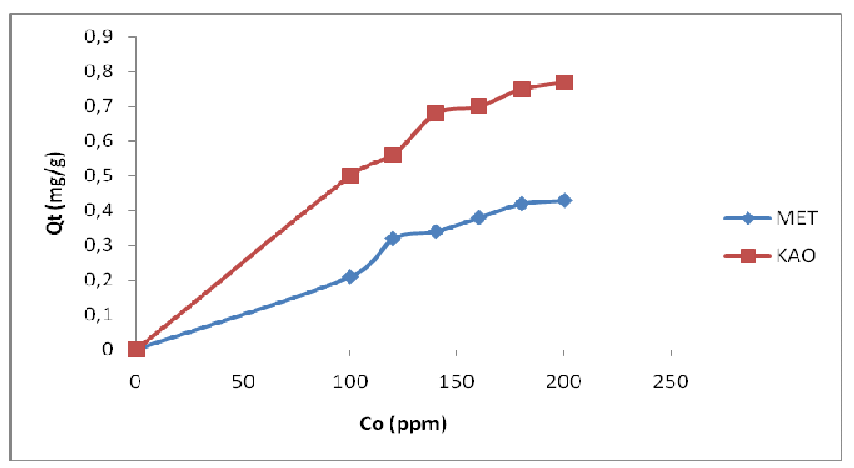

Figure 6: Influence of initial concentration on the sorption of phenol from aqueous solutions. $\left(\mathrm{V}_{\mathrm{o}}=25 \mathrm{~mL} ; \mathrm{C}_{\mathrm{o}}=100 \mathrm{mg} / \mathrm{L}\right.$ phenol solution; $\mathrm{pH}=2$; teq $=40 \mathrm{mins} ; 0.2 \mathrm{~g} \mathrm{KAO}$ and MET; $\mathrm{T}=298 \mathrm{~K}$ ).

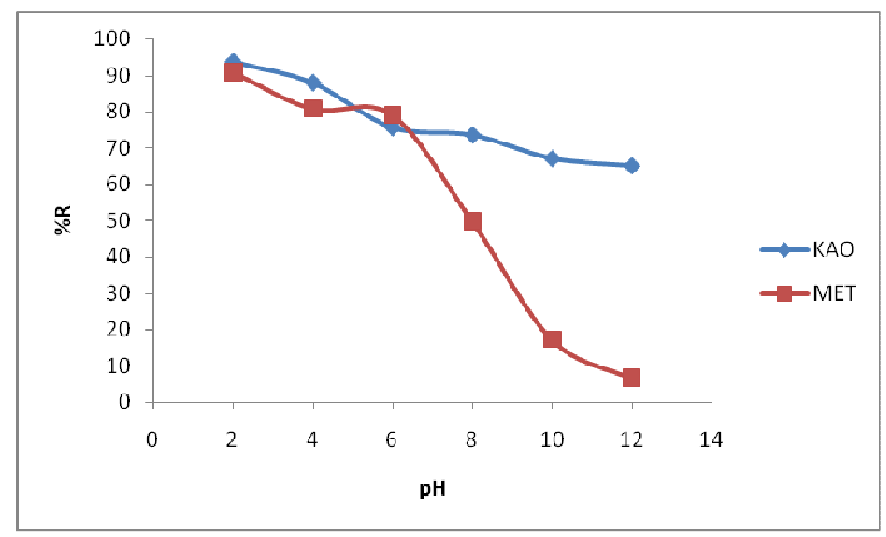

Figure 7: Influence of $\mathrm{pH}$ on the sorption of phenol from aqueous solutions. $\left(\mathrm{V}_{\mathrm{o}}=25 \mathrm{~mL}\right.$; $\mathrm{C}_{\mathrm{o}}=100 \mathrm{mg} / \mathrm{L}$ phenol solution; teq=40 min; $0.2 \mathrm{~g} \mathrm{KAO}$ and MET ; $\mathrm{T}=298 \mathrm{~K}$ ).

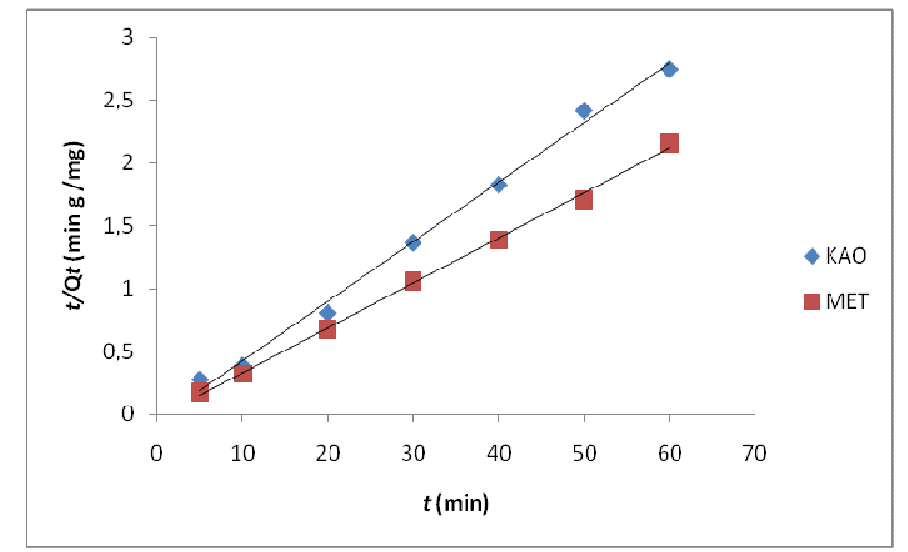

Figure 8: Linear plots of pseudo second-order kinetic model at $100 \mathrm{mg} / \mathrm{L}$ and at $\mathrm{pH}=8$. 


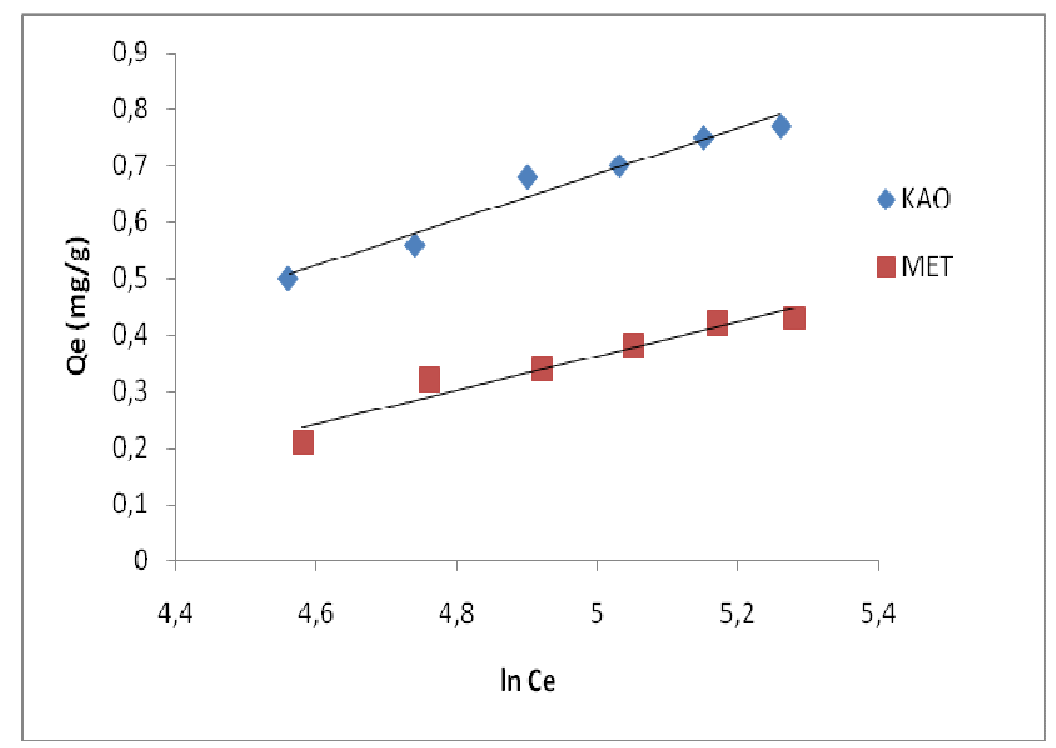

Figure 9: Linear plots of the Temkin isotherm model.

Table 1: Porosity Characteristic of Metakaolinite.

\begin{tabular}{lccccc}
\hline Sample & $\begin{array}{c}\text { BET Specific } \\
\text { surface area } \\
\left(\mathbf{m}^{\mathbf{2}} / \mathbf{g}\right)\end{array}$ & $\begin{array}{c}\text { Average pore } \\
\text { size } \\
(\mathbf{n m})\end{array}$ & $\begin{array}{c}\text { Average pore } \\
\text { diameter } \\
(\mathbf{n m})\end{array}$ & $\begin{array}{c}\text { Total pore } \\
\text { volume } \\
\left(\mathbf{c m}^{\mathbf{3}} / \mathbf{g}\right)\end{array}$ & $\begin{array}{c}\text { Hysterisis } \\
\text { type }\end{array}$ \\
\hline Metakaolinite & 33.8331 & 11.05476 & 9.9178 & 0.093504 & III \\
\hline
\end{tabular}

Table 2. Comparison of the quantity of Phenol Adsorbed by different adsorbents.

\begin{tabular}{lcc}
\hline Author & Adsorbent & $\begin{array}{c}\text { Maximum adsorption } \\
\text { capacity }\end{array}$ \\
\hline Chen et al., 2011 & clay-solidified grouting curtain & $8.4 \mathrm{mg} / \mathrm{g}$ \\
Sofia et al., 2005 & Porous clay Heterostructure & $14.5 \mathrm{mg} / \mathrm{g}$ \\
Djebbar et al., 2012 & Natural Clay & $15.0 \mathrm{mg} / \mathrm{g}$ \\
This Work & KAO & $25.48 \mathrm{mg} / \mathrm{g}$ \\
This Work & MET & $31.1 \mathrm{mg} / \mathrm{g}$ \\
\hline
\end{tabular}


Table 3: Results of linear plots for the adsorption of phenol by KAO and MET.

\begin{tabular}{llcc}
\hline Adsorbent & & KAO & MET \\
\hline $\mathbf{C}_{\mathbf{0}}(\mathbf{m g} / \mathbf{L})$ & & $\mathbf{1 0 0} \mathbf{~ p p m}$ & $\mathbf{1 0 0} \mathbf{~ p p m}$ \\
\hline \multirow{3}{*}{ Pseudo-first-order } & $\mathrm{K}_{1}\left(\mathrm{~min}^{-1}\right)$ & 0.0461 & -0.0041 \\
& $\mathrm{Q}_{\mathrm{e}}(\mathrm{mg} / \mathrm{g})$ & 1.78 & 0.57 \\
& $\mathrm{r}^{2}$ & 0.2352 & 0.0907 \\
\hline \multirow{3}{*}{ Pseudo-second-order } & $\mathrm{K}_{2}(\mathrm{~g} / \mathrm{min} . \mathrm{mg})$ & -0.048 & -0.046 \\
& $\mathrm{Q}_{\mathrm{e}}(\mathrm{mg} / \mathrm{g})$ & 21.14 & 28.01 \\
& $\mathrm{r}^{2}$ & 0.994 & 0.998 \\
\hline \multirow{3}{*}{ Elovich kinetic model } & $\alpha(\mathrm{mg} / \mathrm{g}$ min $)$ & $1.36 \times 10^{19}$ & $-1.05 \times 10^{-42}$ \\
& $\beta(\mathrm{g} / \mathrm{mg})$ & 2.19 & -3.20 \\
& $\mathrm{r}^{2}$ & 0.0253 & 0.0605 \\
\hline \multirow{3}{*}{ Intra-particle diffusion model } & $\mathrm{K}_{\mathrm{d}}\left(\mathrm{mg} / \mathrm{gmin}{ }^{1 / 2}\right)$ & 0.0464 & -0.1869 \\
& $\mathrm{C}(\mathrm{mg} / \mathrm{g})$ & 21.663 & 29.835 \\
& $\mathrm{r}^{2}$ & 0.0013 & 0.1084 \\
\hline
\end{tabular}

Table 4: Summary of the different isotherm plots of the adsorption of phenol by KAO and MET.

\begin{tabular}{lccccccccc}
\hline \multicolumn{1}{c}{ Model } & \multicolumn{3}{c}{ Langmuir } & \multicolumn{3}{c}{ Freundlich } & \multicolumn{2}{c}{ Temkin } \\
\hline Parameter & $\mathbf{K}_{\mathbf{L}}(\mathbf{L} / \mathbf{m g})$ & $\mathbf{Q}_{\mathbf{m}}(\mathbf{m g} / \mathbf{g})$ & $\mathbf{r}^{2}$ & $\mathbf{K}_{\mathbf{F}}(\mathbf{L} / \mathbf{m g})$ & $\mathbf{1} / \mathbf{n}$ & $\mathbf{r}^{2}$ & $\mathbf{A}_{\mathbf{T}}(\mathbf{L} / \mathbf{g})$ & $\mathbf{B}_{\mathbf{T}}(\mathbf{j} / \mathbf{m o l})$ & $\mathbf{r}^{2}$ \\
\hline KAO & 0.0044 & 1.713 & 0.8937 & 0.027 & 0.6398 & 0.9478 & 0.0366 & 6128.05 & 0.9632 \\
\hline MET & 0.000433 & 5.820 & 0.0294 & 0.0029 & 0.9565 & 0.8833 & 0.0224 & 8225.67 & 0.9423 \\
\hline
\end{tabular}

$\mathrm{K}_{\mathrm{L}}$ : Langmuir constant; $\mathrm{Q}_{\mathrm{m}}$ : maximum monolayer capacity; $\mathrm{K}_{\mathrm{F}}$ : Freundlich constant; $\mathrm{A}_{\mathrm{T}}$ and $\mathrm{B}_{\mathrm{T}}$ : Temkin constants

\section{Conclusion}

Adsorption of phenol from aqueous solutions onto KAO and MET materials was carried out by batch mode. Results show that the adsorption capacity of phenol on KAO and MET is affected by $\mathrm{pH}$, initial concentration, contact time, sorbent dose; that quantity adsorbed increased with initial concentration of phenol for an equilibrium time of 40 minutes at $\mathrm{pH}=2$. Adsorption kinetics of phenol (chemisorption) is better described by pseudo second-order, and equilibrium is governed by Freundlich and Temkin isotherm models. The adsorption capacity of samples studied is lower than those of commercial activated carbons. These low values are due to the fact that adsorption of low solubility compounds (phenol and other benzene derivatives) are more feasible with hydrophobic materials (activated carbon, porous polymers) and very insignificant with polar hydrophilic adsorbents (silica gel, alumina). Since adsorption is also influenced by interactions between the adsorbate and the surface functional groups of the adsorbent material, basic treatment or molecular grafting (of amines or thiols onto clay) can help increase the adsorption capacity of the clay samples studied. We infer here that adsorbents employed in this study are comparatively more efficient in the elimination of phenol (toxic organic molecule) from aqueous solutions than others cited in the literature.

\section{ACKNOWLEDGMENTS}

The authors wish to sincerely acknowledge the financial support offered to DTN by the University of Dschang, Cameroon during his post graduate stint and the members of the Physical and Theoretical 
Chemistry Laboratory of the University of Yaounde I, Cameroon, for the technical support to this research endeavor.

\section{REFERENCES}

Achour S, Youcef L. 2003. Elimination du cadmium par adsorption sur bentonite sodique et calcique. Lar. J., 2:68-81.

Anagho SG, Tchuifon TDR, Ndi J, Ketcha JM. 2013. Kinetic and equilibrium studies of the adsorption of mercury (II) ions from aqueous solution using kaolinite and metakaolinite clays from Southern Cameroon. Int. J. Reach. Chem. Env., 3(3) 1-11.

Augustine AA, Orike B, Edidiong AD. 2007. Adsorption kinetics and modeling of $\mathrm{Cu}$ (II) ion sorption from aqueous solution by mercaptoacetic acid modified cassava (Manihot sculenta Cranz) wastes. J. Env. Chem., 6(4): 2221-2234.

Chen H, Zhao J. 2010. Adsorption study for removal of congo red anionic dye using organo-attapulgite. Ads., 15: 381-389.

Chen Y, Ye W, Zhang K. 2011. Factors affecting phenol adsorption on claysolidified grouting curtain. J. Cent. Sth. Univ. Tech., 18: 854-858.

Djebbar M, Djafri F, Bouchekara M, Djafri A. 2012. Adsorption of phenol on natural clay. Applied. W. Sci., 2:77-86.

Dursun A, Kalayei S. 2005. Equilibrium, kinetic and thermodynamic studies on adsorption of phenol onto chitin. J. haz. Mat., 123: 151-157.

Ekpete OA, Horsfall M, Spiff AI. 2012. Removal of chlorophenol from aqueous solution using fluted pumpkin and commercial activated carbon. As. J. Nat \& App. Sci., 1(1): 2186-8476.

Ekpete OA, Horsfall M, Tarawou T. 2010. Potential of fluted pumpkin and commercial activated carbons for phenol removal in aqueous systems. J. Eng. Appl. Sci., 5: 1819-6608.

Franca AS, Leandro SO, Mauro EF. 2009. Kinetics and equilibrium studies of methylene blue adsorption by spent coffee grounds. Desal., 249: 267-272.

Ghogomu JN, Noufame TD, Ketcha MJ, Ndi NJ. 2013. Removal of $\mathrm{Pb}$ (II) Ions from solutions by kaolinite and metakaolinite materials. Brtsh. J. Appl. Sci. Tech., 3(4): 942-961.

Goswamee RL, Sengupta P, Bhattacharyya KG, Dutta DK. 1998.Adsorption of $\mathrm{Cr}$ (VI) in layered double hydroxides. Appl Clay Sci., 13: 21-34.

Grossl, Paul R, Donald L, Sparks. 1994. Rapid Kinetics of $\mathrm{Cu}$ (II) Adsorption/Desorption on Goethite. Env. Sci. Tech., 28:1422-1429.

Hamadi NK, Chen XD, Farid MM, Lu MGQ. 2001. Adsorption kinetics for removal of chromium (VI) from aqueous solution by adsorbents derived from used tyres and sawdust. Chem. Eng. J., 84: 95-105.

Han I, Schlautman MA, Batchelor B. 2000. Removal of hexavalent chromium from ground water by granular activated carbon. Wat. Env. Rech., 72: 29-38.

Ho YS, McKay GA. 1998. Two-Stage batch sorption optimized design for dye removal to minimize contact time. Int. Chem. Eng. Trans., 76(B): 183-191.

Ho YS, Mckay GA. 1999. Competitive sorption of Copper and Nickel Ions from aqueous solution using peat. J. Int. Adsor. Soc., 5:408-417.

Kannam N, Krauppasmy K. 1998. Low cost adsorbents for removal of phenolic acid from aqueous solution. Ind. J. Env. Prot., 18 (9): 683-697.

Ketcha JM, Bougo TC. 2010. Removal of Mercury(II) Ions from Aqueous Solution using Granular Activated Carbon and Kaolinite Clay from Mayouom in Cameroun: Kinetics and Equilibrium Studies. Rsrch J. chem. Env., 14(3): 6066.

Ketcha JM, Ngomo MH, Tcheka C, Ntieche RA, Djoyo HS, Kouatou D. 2009. Batch Equilibrium Adsorption of Cyanides from Aqueous Solution onto Copper- and Nickel-Impregnated Powder Activated 
Carbon and Clay. J. Env. Prot. Sci., 3: $53-57$.

Lazaridis NK, Matis KA, Webb M. 2001. Flotation of metal loaded clay anion exchangers. Part I: the case of chromates. Chemosphere., 42: 373-378.

Maji SJ, Anjali P, Tarasankar P, Asok A. 2007. Adsorption thermodynamics of arsenic on late rite soil. J. Surf. Sci. Tech., 22(3-4):161-176.

Mostafa MR, Sharma SE, Yousef AM. 1989. Removal of organic pollutants from aqueous solution; Part 1, adsorption of phenol by activated carbon. Ind J. Chem. 28(A): 94-108.

Najua DT, Chuah AL, Awani Z, Rahid SA. 2008. Adsorption of Copper from Aqueous Solution by Elais Guineensis Kernel Activated Carbon. J. Eng. Sci. Tech.. 3(2):180-189.

Ola, A. 2007. Kinetic and isotherm studies of copper(II) Removal from wastewater using various adsorbent. Egypt. J. Aqu. Rsch. 33(1):125-143.

Okieimen F, Okieimen C, Wuana A. 2007. Preparation and characterization of activated carbon from rice husk. J. Chem. Soc. Nig. 32: 126-136.

Prpich G, Daugulis A. 2005. Enhanced biodegradation of phenol by a microbial consortium in a solid liquid two phase partitioning bioreactor. Biodegradation. 16: 329-339.

Qadeer R, Rehan H. 2002. A study of the adsorption of phenol on activated carbon from aqueous solutions. Tur. J. Chem., 26: 357- 361 .

Rajesh KR, Rajasimman M, Rajamohan N, Sivaprakash B. 2010. Equilibrium and Kinetic Studies on Sorption of Malachite Green using Hydrilla Verticillata Biomass. Int. J. Env. Research., 4: 817824.

Singh B, Mish N, Rawat N. 1994. Sorption characteristic of Phenols on fly ash and impregnated fly ash. Ind. J. Env. Hlth., $\mathbf{3 8}$ (1):1-14.

Sofia A, Tzayhiri G, Guillermo O, Madel S, Brenda P. 2005. Adsorption of phenol and chlorophenol from aqueous solutions by porous clay heterostructure (PCH). $J$. Mex. Chem. Soc., 49(3): 287-291.

Tahir H, Saleen M, Afzal M, Ahmad H, Hussain ST, Afjal J. 1998. Estimation and removal of chromium ion from tannery wastes using Zeolite-3A. Ads. Sci. Tech., 16: $153-161$.

Theivarasu C, Mylsamy S, Sivakumar N. 2011. Cocoa shell as adsorbent for the removal of methylene blue from aqueous solution: Kinetic and equilibrium study. Univ. J. Env. Rsrch. Tech., 1 :70-78.

Uddin M, Islam M, Abedin M. 2007. Adsorption of phenol from aqueous solution by water hyacinth. J. Eng. Appl. Sci., 2: 11-16.

Xiu-yan P. 2010. Adsorption Kinetics and Thermodynamic characteristics of expanded graphite for polyethylene glycol."Env. J. Chem. 7(4): 1346-1358. 